\title{
Anti-inflammatory Effect of Brazilin in RAW264.7 Cells
}

Joong Hyun Shim

Faculty of Cosmetics and Beauty Biotechnology, Semyung University, Jecheon-si, Chungcheongbuk-do, Korea

Corresponding author: Joong Hyun

Shim, Faculty of Cosmetics and Beauty

Biotechnology, Semyung University, 65

Semyung-ro, Jecheon-si, Chungcheongbuk-

do 27136 , Korea

Tel.: +82436491615

Fax: +82 436491730

Email: jhshim@semyung.ac.kr

Received January 2, 2019

Revised January 28, 2019

Accepted January 28, 2019

Published March 30, 2019

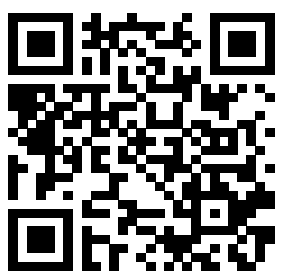

\begin{abstract}
Purpose: This study aimed to determine the skin anti-inflammatory effect of brazilin on RAW264.7 cells. Methods: To determine anti-inflammatory effects of brazilin on RAW264.7 cells, we measured cell viability, gene expressions, and prostaglandin $\mathrm{E}_{2}\left(\mathrm{PGE}_{2}\right)$ /nitric oxide (NO) production. Results: Cells were treated with brazilin to confirm cytotoxicity; no toxicity was observed when cells were treated at a concentration of $\leq 1 \mu \mathrm{g} / \mathrm{mL}$. In RAW264.7 cells, the number of intracellular granule were increased after lipopolysaccharide (LPS) treatment; however, brazilin treatment decreased intracellular granules similar to that in the control group. In this research, we elucidated the anti-inflammatory effects of brazilin on the mRNA expression of interleukin 1 alpha $(I L 1 \alpha)$, interleukin 1 beta $(I L 1 \beta)$, interleukin 6 (IL6), and tumor necrosis factor alpha $(T N F \alpha)$ and $\mathrm{PGE}_{2} / \mathrm{NO}$ production. Real-time reverse transcription polymerase chain reaction (real-time RT-PCR) showed that brazilin administration increased the mRNA levels of IL1 $\alpha / I L 1 \beta / I L 6 / T N F \alpha$ genes, and analysis of $\mathrm{PGE}_{2} / \mathrm{NO}$ also revealed that brazilin induces anti-inflammatory effects. Conclusion: We identified the anti-inflammatory effect of brazilin, and found that brazilin can be a potent cosmetic ingredient for anti-inflammatory agent for atopic dermatitis. Based on this result, we believe that brazilin has the potential to be used in not only cosmetics, but also medicine or healthcare food.
\end{abstract}

Keywords: Brazilin, Anti-inflammatory, Nitric oxide, $\mathrm{PGE}_{2}$, TNF $\alpha$

\section{Introduction}

염증은 손상된 세포, 자극원 및 박테리아를 포함한 유해한 자극에 대한 조직 보호 면역 반응으로 알려져 있다(Albina \& Reichner, 1995). 그러나 염증이 과도하게 유발되면 아테로마 성동맥경화증, 고혈압, 당뇨병, 암 및 신경 퇴행성 장애 등과 같 은 다양한 질병을 통해 세포 및 조직 손상을 유도 할 수 있다

(Albina \& Reichner, 1995).

면역계는 화학적, 물리적 또는 감염성 스트레스에 대한 염 증 매개 반응을 일으킨다(Kim et al., 2004). 대식세포는 면 역 반응 동안 여러 생물학적 과정에 중요한 역할을 하는 세포 로써 염증반응에서 항원 제시, 식균 작용 및 면역 조절과 같은 세 가지 주요 기능을 담당하기 위해 다양한 싸이토카인 및 성 장인자를 방출한다(Akira \& Takeda, 2004; Gomez et al., 2005). 손상되거나 활성화된 대식세포는 다양한 염증 매개체 를 방출함으로써 염증 반응을 조절할 수 있다(Fujiwara et al.,
2005). Lipopolysaccharide (LPS)는 대식세포의 toll-like receptor (TLR)에 결합하여 세포 내 신호전달경로인 mitogenactivated protein kinase (MAPK)와 nuclear factor kappa beta ( $\mathrm{NF} \kappa \mathrm{B})$ 신호의 활성화를 유도하고, nitric oxide (NO), $\mathrm{PGE}_{2}$ 와 같은 염증성 매개인자를 분비하고 interleukin 1 (IL1), interleukin 6 (IL6), tumor necrosis factor $\alpha(\mathrm{TNF} \alpha)$ 와 같 은 염증성 싸이토카인을 증가시킨다(Akira \& Takeda, 2004; Gomez et al., 2005). 이렇게 생성된 염증 매개인자들은 주변세 포의 면역기능을 활성화시키는 중요한 역할을 하기도 하지만 과 량의 $\mathrm{NO}$ 와 $\mathrm{PGE}_{2}$ 등은 질병을 악화시키는 원인이 되기도 한다 (Kim et al., 2004). NO는 염증의 대표적 지표물질로, 일반적 인 NO는 박테리아와 같은 미생물을 죽이거나 종양을 억제하는 중요한 역할을 하지만 염증에서의 과도한 $\mathrm{NO}$ 는 조직손상, 유전 적 변이 및 신경손상을 유발한다(Gabay, 2006; Im, 2014; Lee et al., 2014; Van Triel et al., 2010). 또한 cyclooxygenase 2 (COX2)는 arachidonic acid로부터 염증 매개물질인 $\mathrm{PGE}_{2}$ 생 


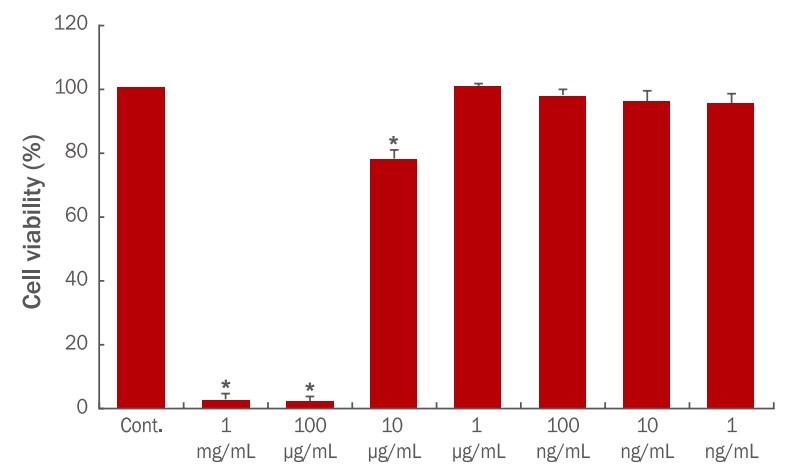

Figure 1. Cytotoxicity of brazilin in RAW264.7 cells.

RAW264.7 cells $\left(4 \times 10^{3}\right.$ cells/well) were seeded in 96-well tissue culture plate and treated brazilin extracts for $24 \mathrm{~h}$. Cell viability assay was measured by CCK- 8 solution. These results are presented as the mean \pm standard deviation of the percentage of control optical density in triplicate. ${ }^{*}$ means compared to control $\left({ }^{*} p<0.05\right)$.

성을 유도하는 효소로서 $\mathrm{iNOS}$ 와 함께 염증반응에 중요한 역할을 담당한다. LPS에 의한 대식세포의 활성 시 $\mathrm{NO}$ 와 $\mathrm{PGE}_{2}$ 는 IL 1 및 $\mathrm{TNFa}$ 와 같은 염증성 싸이토카인 등을 생산한다(Horwood et al., 2006; Hirohashi \& Morrison, 1996). 따라서 NO의 생성이나 $\mathrm{PGE}_{2}$, 염증성 싸이토카인의 발현억제는 염증성 질환을 치료하거 나 예방하는데 있어 중요한 목표가 된다.

브라질린(brazilin, (6a S-cis)-7,11b-dihydrobenz[b] indeno[1,2-d]pyran-3,6a,9,10(6H)-tetrol)은 말레이시아, 인 도, 중국 남부 등의 열대 아시아에 분포하는 소목(Caesalpinia sappan L.)의 주성분으로 알려져 있다. 소목은 천연의 적색 색소 를 함유하고 있는데, 염료나 산 및 알칼리 지시약 또는 식품 첨가 물 등으로 사용되어 왔다(Puchtler et al., 1986). 최근의 연구결 과에 따르면 월경폐색, 어혈에 의한 타박손상, 혈당저하, 고혈압, 항염작용, 항균작용, 항노화 등의 다양한 생리학적 효능을 지녔 다고 보고되었다(Hwang et al., 1998; Hwang \& Shim, 2018; Moon et al., 1992). 하지만 브라질린이 RAW264.7 세포에서의 염증 완화에 효과적인지에 대한 연구는 없다. 본 연구에서는 LPS 에 의해 자극이 유발된 RAW264.7 세포에 브라질린을 처리하였

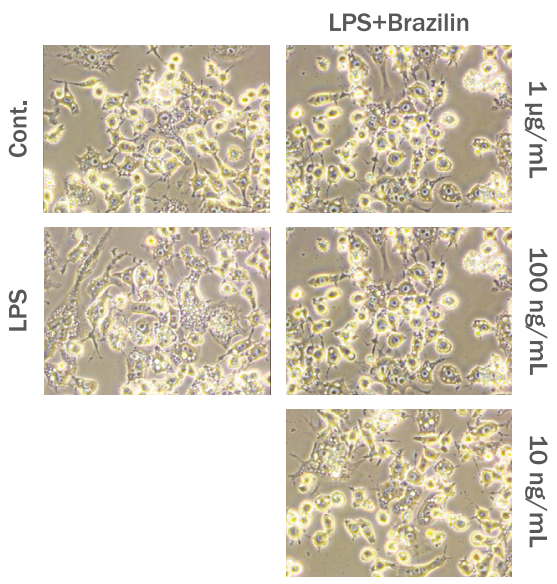

Figure 2. Effects of brazilin on the LPS-activated morphological changes in RAW 264.7 cells.

The morphologies of RAW264.7 cells were visualized with a phase contrast microscopy (X400). The cells were treated with brazilin for $24 \mathrm{~h}$. Scale bar: $20 \mu \mathrm{m}$. LPS, lipopolysaccharide.

을 때의 항염증 효과를 확인하였다. 브라질린에 의한 RAW264.7 세포 생존률, $\mathrm{mRNA}$ 와 $\mathrm{NO}, \mathrm{PGE}_{2}$ 단백질 발현을 Cell Counting Kit-8 (CCK-8) 분석, real-time RT-PCR 및 enzyme-linked immunosorbent assay (ELISA) 분석법으로 각각 확인하였다.

\section{Methods}

\section{1. 세포배양}

RAW264.7 대식세포는 한국세포주은행(Korean Cell Line Bank, Korea)을 통해 구입하여 사용하였다. Fetal bovine serum (FBS; Welgene, Korea)과 penicillin/streptomycin (Welgene) 이 첨가된 Dulbecco's modified Eagle's medium (DMEM; Welgene)을 RAW264.7 대식세포 배양에 사용했다. RAW264.7 대식세포는 $5 \% \mathrm{CO}_{2}, 37^{\circ} \mathrm{C}$, 습도 $100 \%$ 조건의 인큐베이터에서 배 양하였다.

Table 1. Gene name and assay ID number in real-time RT-PCR analysis

\begin{tabular}{|c|c|c|}
\hline Symbol & Gene name & Assay ID \\
\hline NOS2 & Nitric oxide synthase 2 , inducible & Mm00440502_m1 \\
\hline $\operatorname{cox} 2$ & Cyclooxygenase 2 & Mm03294838_g1 \\
\hline$I L 1 \alpha$ & Interleukin 1 alpha & Mm00439620_m1 \\
\hline$I L 1 \beta$ & Interleukin 1 beta & Mm00434228_m1 \\
\hline IL6 & Interleukin 6 & Mm00446190_m1 \\
\hline$T N F \alpha$ & Tumor necrosis factor alpha & Mm00443258_m1 \\
\hline GAPDH & Glyceraldehyde-3-phosphate dehydrogenase & Mm99999915_g1 \\
\hline
\end{tabular}

RT-PCR, reverse transcription-polymerase chain reaction. 


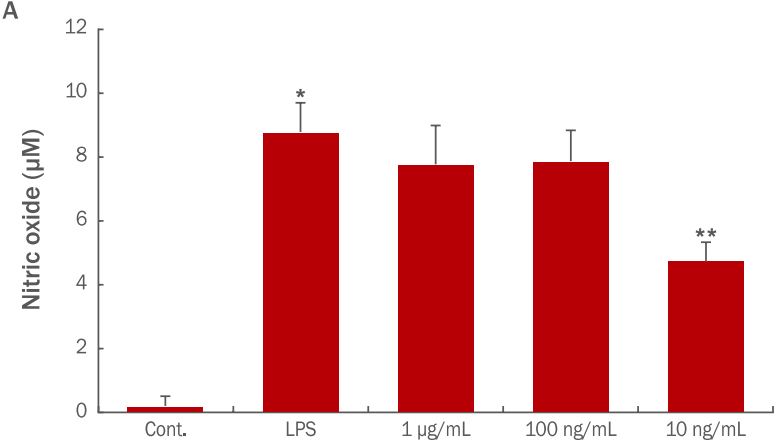

B

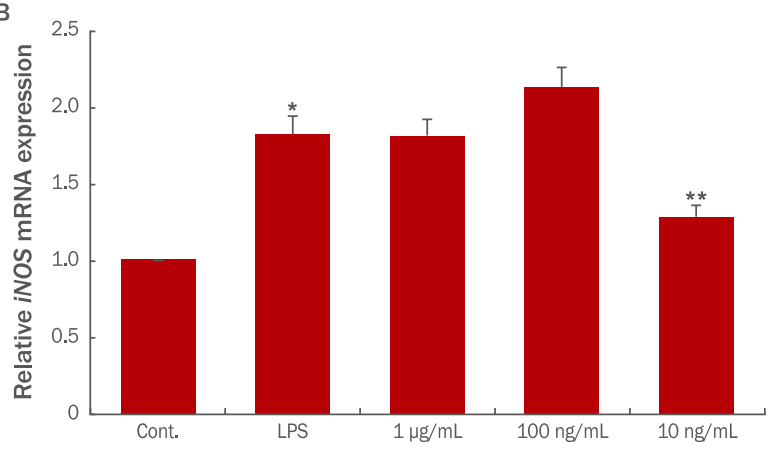

Figure 3. Effects of brazilin on NO synthesis in RAW 264.7 cells.

RAW264.7 cells were seeded in $35 \mathrm{~mm}$ culture dish, treated with brazilin for $24 \mathrm{~h}$. And medium of the cell were collected and analyzed for NO detection kit (A). Real-time RT-PCR analysis of the iNOS (B). The data represent the mea \pm standard deviation of three independent experiments. ${ }^{*}$ means compared to control, ${ }^{* *}$ means compared to LPS-treated condition $\left({ }^{*},{ }^{* *} p<0.05\right)$. NO, nitric oxide; iNOS, inducible nitric oxide synthase; RT-PCR, reverse transcription-polymerase chain reaction.

\section{2. 세포 생존율 검증}

세포 생존율은 CCK-8 (Dojindo, Japan)를 사용하여 측정하 였다. 세포를 조직 배양 접시에 접종하고 $24 \mathrm{~h}$ 동안 안정화 시킨 후, 브라질린을 농도 별로 $24 \mathrm{~h}$ 처리하였다. 이후 phenol-red가 들어있지 않은 DMEM에 CCK-8 시약을 $1 / 10$ 로 희석하여 인큐 베이터에서 $1 \mathrm{~h}$ 동안 반응시켰다. Microplate reader (BioTek, USA)를 이용하여 $450 \mathrm{~nm}$ 파장에서 흡광도를 측정하고, 세포가 첨가되지 않은 대조군의 흡광도를 기초로 하여 세포 생존율을 계 산하였다. 세포 생존율은 대조군에 대한 백분율로 표기하였다.

\section{3. 실시간 유전자 중합효소 연쇄반응(Real-time RT-PCR)}

Life technologies사의 TRIzol Reagent (USA)를 사용 하여 세포의 total RNA를 추출하였다. 추출한 RNA로부터 SuperiorScript III 역전사효소 키트(Enzynomics, Korea)를 사 용하여 $\mathrm{cDNA}$ 를 합성하였으며, RAW264.7 대식세포 표지인자 의 발현을 비교 측정하기 위하여 StepOnePlus PCR machine (Applied Biosystems, USA)을 사용하여 Real-time RT-PCR 을 진행하였다. 실험에 사용된 Taqman Gene expression assay (Applied Biosystems)는 Table 1에 정리하였다.

\section{4. $\mathrm{NO}$ 정량}

RAW264.7 대식세포를 $35 \mathrm{~mm}$ 조직 배양 접시에 $40 \times 10^{5}$ cells로 분주하고 $24 \mathrm{~h}$ 동안 전 배양한 후, lipopolysaccharide (LPS; Sigma-Aldrich, USA) $(1 \mu \mathrm{g} / \mathrm{mL})$ 와 브라질린을 첨가하 여 $24 \mathrm{~h}$ 동안 배양 후, 배양액을 수집하여 원심분리한 후 상등액 $100 \mu \mathrm{L}$ 를 사용하여 NO의 생성량을 NO detection kit (iNtRON, Korea)를 사용하여 제조사의 프로토콜에 따라 측정하였다. 프 로토콜을 간략히 기술하면, 상등액 $100 \mu \mathrm{L}$ 에 $50 \mu \mathrm{L}$ 의 N1 버퍼 (iNtRON, Korea)를 첨가하여 $10 \mathrm{~min}$ 간 상온에 반응시키고 N2
버퍼(iNtRON)를 $50 \mu \mathrm{L}$ 추가하여 $10 \mathrm{~min}$ 간 반응시킨 후 $520-$ $560 \mathrm{~nm}$ 의 파장에서 ELISA reader (EPOCH; BioTek, USA)로 흡광도를 측정하였다.

\section{5. $\mathrm{PGE}_{2}$-효소결합면역흡착검사법}

브라질린이 $\mathrm{PGE}_{2}$ 의 생성에 끼치는 영향을 알아보기 위하여 RAW264.7 대식세포를 $24 \mathrm{~h}$ 동안 인큐베이터에서 전 배양한 후, $1 \mu \mathrm{g} / \mathrm{mL}$ 의 LPS와 브라질린을 농도별로 첨가하여 $6 \mathrm{~h}$ 동안 배양 하였다. PGE $\mathrm{F}_{2}$-ELISA kit (Pierce Endogens, USA)를 이용하여 제조사의 프로토콜을 따라RAW264.7 대식세포가 분비하는 배양 액 내의 $\mathrm{PGE}_{2}$ 의 양을 측정하였다.

\section{6. 통계분석}

통계처리는 Student's $t$-test방법을 이용하여 유의 수준을 $0.05(p<0.05)$ 로 하여 검정하였다.

\section{Results \& Discussion}

\section{1. 브라질린의 농도별 세포 생존율 분석}

본 연구에서 사용된 RAW264.7 대식세포는 마우스 유래 대식 세포주이며, LPS에 의해 염증반응이 활성화되어 염증성 싸이토 카인을 방출하는 것으로 알려져 있다. 대식세포는 인체 전반에 분 포하고 있으며 염증성 인자에 즉각적인 방어를 제공하는 면역세 포이며, 후천성 면역을 유도하는 항원제시 세포로서의 역할 및 다 양한 싸이토카인을 분비하는 세포이다(Lawrence et al., 2002). 브라질린의 항염증 효능을 확인하기에 앞서 연구에 사용하고 자 하는 브라질린의 독성여부를 확인하기 위하여 CCK-8 assay 를 수행하였다. 대조군은 시료를 처리하지 않았고 브라질린은 1 

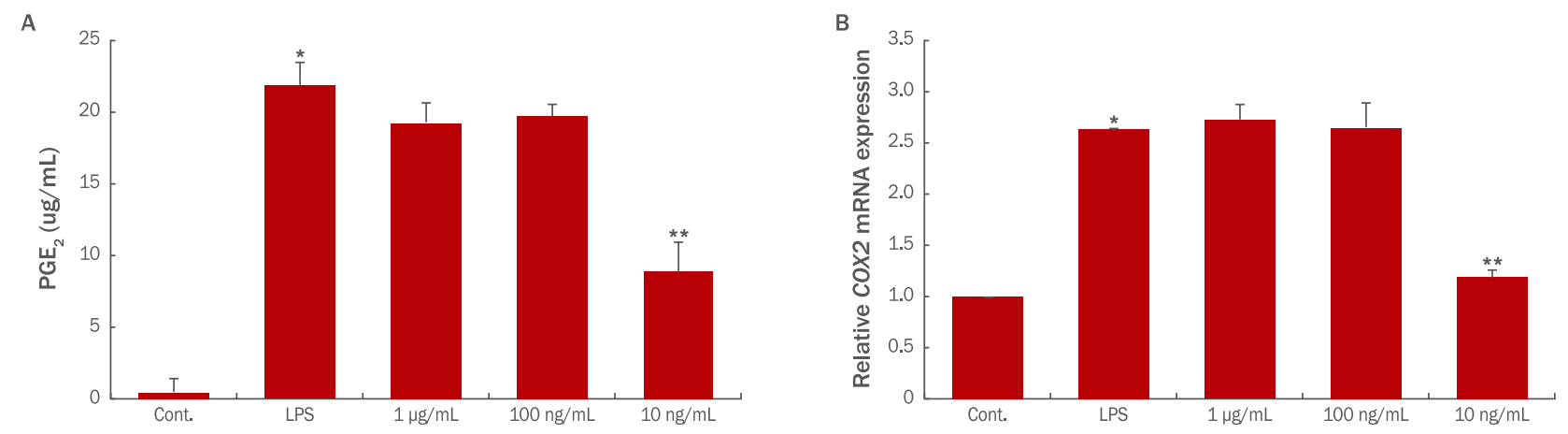

Figure 4. Effects of brazilin on $\mathrm{PGE}_{2}$ synthesis in RAW 264.7 cells.

RAW264.7 cells were seeded in $35 \mathrm{~mm}$ tissue culture dish, treated with brazilin for $24 \mathrm{~h}$. And medium of the cell was collected and analyzed for PGE 2 -ELISA (A). Real-time RT-PCR analysis of the COX2 (B). The data represent the mean \pm standard deviation of three independent experiments. * means compared to control, ${ }^{* *}$ means compared to LPS-treated condition $\left({ }^{*},{ }^{* *} p<0.05\right)$. PGE ${ }_{2}$, prostaglandin 2; COX2, cyclooxygenase 2; ELISA, enzyme-linked immunosorbent assay.

$\mathrm{mg} / \mathrm{mL}, 100,10,1 \mu \mathrm{g} / \mathrm{mL}, 100,10,1 \mathrm{ng} / \mathrm{mL}$ 의 농도로 각각 처리하여 세포 생존율을 측정하였다(Figure 1). $10 \mu \mathrm{g} / \mathrm{mL}$ 이상 의 농도에서 RAW264.7 대식세포의 생존율이 유의성 있게 감소 하였고, $1 \mu \mathrm{g} / \mathrm{mL}$ 이하의 농도로 처리시에는 RAW 264.7 대식세 포의 생존율이 대조군과 유사하여 본 실험에서는 $1 \mu \mathrm{g} / \mathrm{mL}, 100$, $10 \mathrm{ng} / \mathrm{mL}$ 의 브라질린을 처리하여 추가실험을 진행하였다.

\section{2. 브라질린이 RAW264.7 세포의 형태에 미치는 영향}

LPS는 대식세포를 활성화시키는 인자로 대식세포의 형태를 급격히 변화시키는 물질로 알려져 있다(Xu et al., 2015). 특 별히 항염물질은 LPS에 의해 변화가 유발된 대식세포의 형태 를 회복시킨다고 알려져 있다(Hong et al., 2002; Park et al., 2011). 따라서 본 연구에서 브라질린이 LPS에 의해 자극이 유도 된 RAW264.7 세포의 형태를 회복시키는지 확인하기 위하여 위 상차 현미경(CKX41; Olympus, Japan) (배율: X400)을 통하여 확인하였다. 대조군 세포는 일반적으로 배양접시 바닥 면에 넓게 부착되기 보다는 구형의 형태로 부착되어 있고 세포질 내 소과립 의 생성이 적은 반면, LPS로 자극이 유발된 처리군은 위족과 유 사한 형태를 보이며 배양접시 바닥 면에 넓게 부착되고 세포질 내 소과립이 증가되어 있는 양상을 보인다. 브라질린을 각 농도별로 $24 \mathrm{~h}$ 처리한 실험군 중 특별히 $10 \mathrm{ng} / \mathrm{mL}$ 의 브라질린을 처리한 실험군에서 대조군과 유사한 형태로 회복이 됨을 확인할 수 있었 다(Figure 2). 이는 브라질린이 LPS에 의한 대식세포의 형태학적 변화를 감소시킴을 설명하며, 이러한 형태학적 변화 및 회복이 대 식세포의 기능에 미치는 영향에 대한 연구가 추가적으로 진행되 어야 할 것으로 사료된다.

\section{3. 브라질린이 NO 생성에 미치는 영향}

체내에서 $\mathrm{NO}$ 는 세균과 종양을 제거하고 신경전달을 매개하거
나 혈압을 조절하는 등 다양한 역할을 담당하는 중요한 인자로 알려져 있다(Lee et al., 2014). 그러나 높은 수준으로 생성되는 $\mathrm{NO}$ 는 조직과 신경의 손상을 유발하고, 유전자의 변이를 유도하 거나, 부종을 유발하는 등 과도한 염증반응을 일으킨다(Gabay, 2006; Im, 2014; Van Triel et al., 2010). 본 연구에서 브라질 린의 $\mathrm{NO}$ 감소 효능을 확인한 결과, LPS에 의해 $8.8 \mu \mathrm{M}$ 농도로 생성된 $\mathrm{NO}$ 가 $10 \mathrm{ng} / \mathrm{mL}$ 의 브라질린을 처리하였을 때 $4.7 \mu \mathrm{M}$ 로 나타나, LPS 처리군에 비해 NO 생성이 유의성 있게 감소한 것으로 나타났다(Figure $3 \mathrm{~A}$ ).

$\mathrm{LPS}$ 는 대식세포에서 $\mathrm{iNOS}$ 라는 염증매개 인자의 생성을 촉진 하여 NO의 생성을 증가시킨다(Namazi, 2004). 따라서 NO를 증가시키는 효소인 iNOS 유전자 발현을 브라질린이 감소시키는 지 확인하고자 Real-time RT-PCR을 수행하였다. iNOS의 발 현이 LPS 처리군에서 현저히 증가하였으나 $10 \mathrm{ng} / \mathrm{mL}$ 의 브라질 린을 처리한 세포주에서는 LPS 처리군 대비 유의성 있게 감소하 였다(Figure 3B).

\section{4. 브라질린이 PGE2의 생성에 미치는 영향}

Prostaglandin (PG)는 arachidonic acid로부터 유래한 불 포화지방산으로 염증반응을 유도하는 호르몬으로 알려져 있다 (Yun et al., 2008). $\mathrm{PG}$ 의 한 종류인 $\mathrm{PGE}_{2}$ 는 염증반응에 깊이 관여하고, cyclooxygenase-2 (COX2) 유전자에 의하여 생성된 다. $\mathrm{COX} 2$ 가 과발현할 경우에는 $\mathrm{PGE}_{2}$ 의 생성이 증가되어 통증, 발열 및 염증반응이 유발된다(Harris et al., 2002; Namazi, 2004). 브라질린의 항염 효능을 확인하기 위하여 브라질린의 $\mathrm{PGE}_{2}$ 감소 여부를 분석한 결과, $\mathrm{LPS}$ 처리군에서는 $\mathrm{PGE}_{2}$ 의 생 성이 $22.2 \mu \mathrm{g} / \mathrm{mL}$ 로 대조군에 비해 증가하였다. 그에 비해 10 $\mathrm{ng} / \mathrm{mL}$ 의 브라질린을 처리하였을 때에는 $\mathrm{PGE}_{2}$ 의 생성이 $9 \mu \mathrm{g} /$ $\mathrm{mL}$ 로 나타나 LPS 처리군에 비해 $\mathrm{PGE}_{2}$ 생성이 현저히 감소하였 

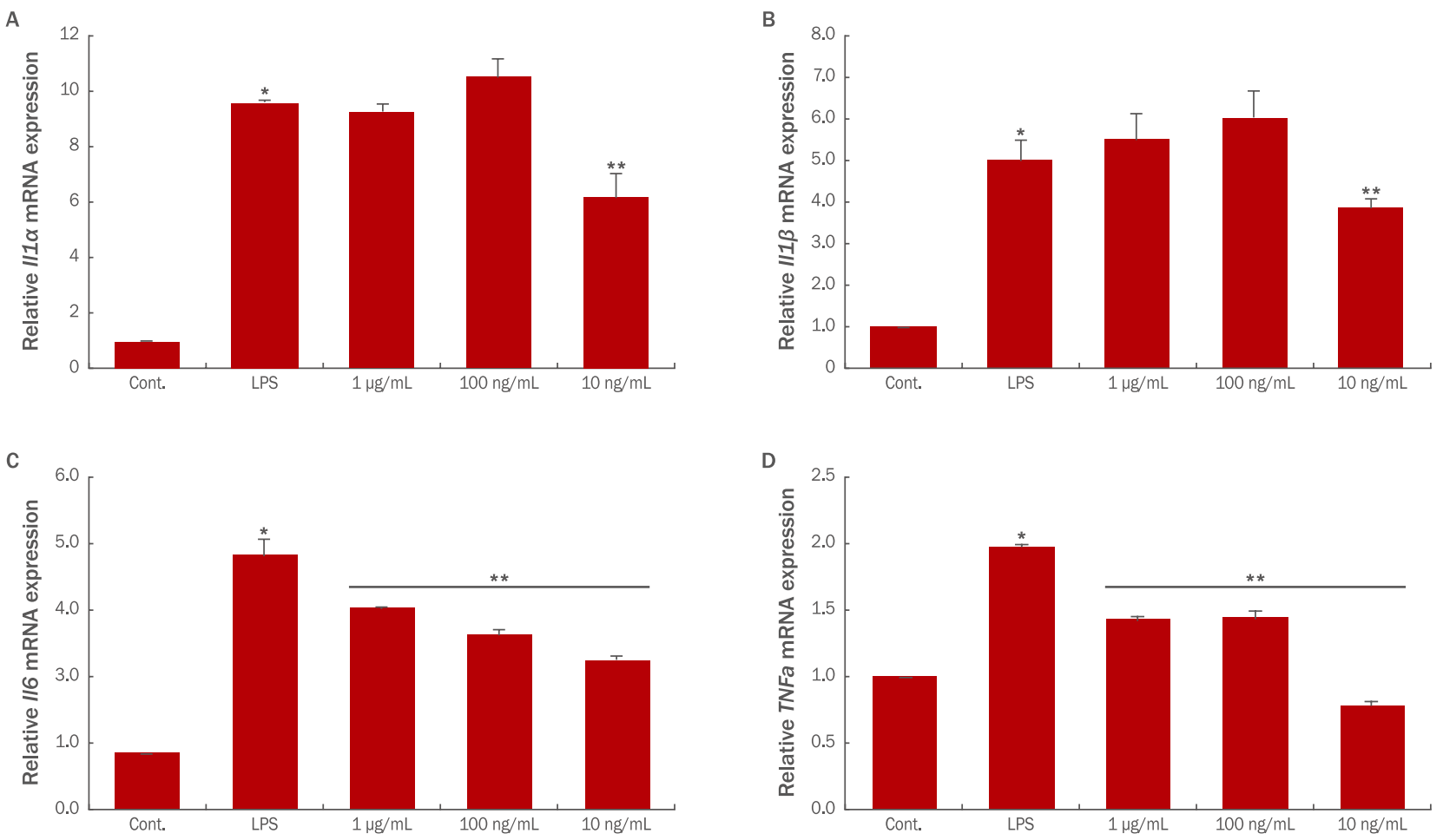

Figure 5. Effects of the brazilin on the expressions of inflammatory cytokines.

Real-time RT-PCR analysis of the pro-inflammatory transcription factors such as $I L 1 \alpha(\mathrm{A}), I L 1 \beta(\mathrm{B})$, IL6 (C), and TNF $\alpha$ (D). The graphs are shown as the mean \pm standard deviation of three independent experiments. ${ }^{*}$ means compared to control, ${ }^{* *}$ means compared to LPS-treated condition $\left({ }^{*},{ }^{* *} p<0.05\right)$. IL1 $\alpha$, interleukin $1 \alpha ; / L 1 \beta$, interleukin $1 \beta$; IL6, interleukin 6; TNF $\alpha$, tumor necrosis factor $\alpha$; LPS, lipopolysaccharide; RT-PCR, reverse transcription-polymerase chain reaction.

다(Figure 4A). COX2 유전자의 발현은 LPS 처리군에서 2.6배 증가하였으나 $10 \mathrm{ng} / \mathrm{mL}$ 의 브라질린을 처리한 세포주에서는 유 의성 있게 감소하였다(Figure $4 \mathrm{~B}$ ).

\section{5. 브라질린이 염증성 싸이토카인의 생성에 미치는 영향}

피부에서 나타나는 만성적인 염증은 피부질환 뿐 아니라 피부 의 노화를 촉진시키는 인자가 된다(Noman et al., 2009; Shon et al., 2013; Lee et al., 2014). IL1 $\alpha$ 와 IL1 $\beta$ 는 다양한 면역반 응, 염증과정 및 조혈에 관여하는 싸이토카인으로 활성화된 대식 세포와 면역반응이 유도된 B 림프구 및 섬유아세포 등에서 생성 되는 염증의 강력한 매개체이다(Ban et al., 2011; Lord et al., 1991). 특별히 IL $1 \beta$ 는 염증부위에 림프구와 호중구 등의 염증세 포 침윤을 상승시키는 싸이토카인으로 알려져 있다(Baek et al., 2012; Roitt et al., 2001). IL6는 B 림프구의 성장과 분화를 유 도하고, 알러지를 포함한 만성적 염증성 질환을 유발한다고 알려 져 있다(Gabay, 2006; Lee et al., 2014). 또한, $\mathrm{TNF} \alpha$ 는 염증 초기에 염증 부위로 호중구를 유인하여 부종을 유발시키고, 급성 면역반응을 유도하는 인자이다(Zhang et al., 1992).

$\mathrm{LPS}$ 는 대식세포에서 인터류킨류와 $\mathrm{TNF} \alpha$, iNOS 등의 염증
매개 인자의 생산을 촉진한다. 본 실험에서는 $1 \mu \mathrm{g} / \mathrm{mL}$ 농도의 LPS를 처리하여 대식세포의 염증반응을 유도하였다. 본 연구에 서 브라질린의 염증성 싸이토카인의 감소효과를 확인한 결과, $\mathrm{IL} 1 \alpha$ 는 LPS 처리군에 의해 9.6 배 증가하였으나 $10 \mathrm{ng} / \mathrm{mL}$ 의 브라질린을 처리하였을 때 $36 \%$ 가량 발현이 감소하였다(Figure $5 \mathrm{~A})$. IL $1 \beta$ 는 $10 \mathrm{ng} / \mathrm{mL}$ 의 브라질린을 처리하였을 때 LPS 처리 군에 비하여 $23 \%$ 가량 발현이 감소하였다(Figure 5B). IL6는 1 $\mu \mathrm{g} / \mathrm{mL}, 100,10 \mathrm{ng} / \mathrm{mL}$ 의 브라질린을 처리하였을 때 LPS 처 리군에 비하여 각각 $21 \%, 31 \%, 41 \%$ 가량 발현이 감소하였다 (Figure $5 \mathrm{C}$ ). $\mathrm{TNF} \alpha$ 는 브라질린 $1 \mu \mathrm{g} / \mathrm{mL}, 100,10 \mathrm{ng} / \mathrm{mL}$ 의 농도에서 LPS 처리군에 비해 각각 $28 \%, 27 \%, 60 \%$ 가량 발현이 감소하였다(Figure 5D).

\section{Conclusion}

피부는 노화에 의하여 주름이 생성되고 두꺼워지고 염증 등의 증상이 난다. 자외선과 미세먼지, 세균 등과 같은 외부환경에 의 해 피부는 활성산소종과 $\mathrm{NO}$ 의 연쇄 반응을 통해 노화가 촉진되 
고 염증질환 등이 발생한다(Kim et al., 2011; Talwar et al., 1995). 또한 노화는 성체 내 존재하는 구성세포의 감소, 혹은 기 능저하에 의해 정상적인 기능을 하는 조직으로의 재생 기능을 하 지 못하게 된다(Jones \& Rando, 2011; Kirkwood, 2005).

본 연구에서 브라질린을 RAW264.7 대식세포에 처리할 적절 한 농도를 확인할 수 있었다. $1 \mu \mathrm{g} / \mathrm{mL}$ 이하의 농도에서는 대식 세포의 생존율에 영향을 미치지 않음을 Figure 1에서 확인하였 다. 그리고 $10 \mathrm{ng} / \mathrm{mL}$ 농도의 브라질린이 LPS에 의해 자극이 유도된 대식세포의 형태변화를 대조군과 유사하게 회복시킬 수

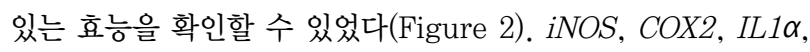
$I L 1 \beta, I L 6$ 와 $T N F \alpha$ 의 유전자 발현 측정과 $\mathrm{NO}$ 생성량 측정, $\mathrm{PGE}_{2}$ 단백질 발현 측정에서 $10 \mathrm{ng} / \mathrm{mL}$ 농도의 브라질린이 유의 성 있게 LPS에 의해 증가된 염증에 관여하는 인자의 발현이 회 복되는 결과를 나타내었다(Figure 3-5). 이는 브라질린이 새로 운 피부 염증개선 후보물질로서의 가능성을 보여준다.

본 연구에서 브라질린이 염증에 관여하는 전사인자의 발현을 억제시켰으며, $\mathrm{NO}$ 와 $\mathrm{PGE}_{2}$ 등의 생성 모두 농도 의존적으로 감 소시킴을 통하여 항염증 효능을 확인하였고, 염증성 질환 및 피 부노화를 개선하는 치료제 또는 기능성 화장품 원료로서 브라질 린이 유용할 수 있음을 보여주는 기초적인 자료가 될 것으로 사 료된다. 대식세포의 형태와 LPS와의 관계, 그리고 항염 소재 가 대식세포의 형태를 회복하는 기전에 대한 기초연구가 진행되 어야 할 것으로 보인다. 또한 향후 브라질린이 어떠한 기전으로 LPS에 의해 염증이 유발된 피부를 개선하는지에 대해 추가연구 와 심도있는 임상연구가 필요할 것으로 보인다.

\section{Acknowledgements}

이 논문은 2019학년도 세명대학교 교내학술연구비 지원에 의 해 수행된 연구임.

\section{References}

Akira S, Takeda K. Toll-like receptor signaling. Nature Reviews Immunology, 4: 499-511, 2004.

Albina JE, Reichner JS. Nitric oxide in inflammation and immunity. New Horizons, 3: 46-64, 1995.

Baek YM, Choi JY, Lee CW, Jeon YS, Han JT, Jang SI, Yoo HS. Effects of Chinemys reevesii on lipopolysaccarideindused inflammatory reactions. Journal of Physiology and Pathology in Korean Medicine, 26: 26-34, 2012.

Ban JY, Kim BS, Kim SC, Kim DH, Chung JH. Microarray analysis of gene expression profiles in response to treatment with melatonin in lipopolysaccharide activated RAW 264.7 Cells. The Korean Journal of Physiology \& Pharmacology, 15: 23-29, 2011.

Fujiwara N, Kobayashi K. Macrophages in inflammation. Inflammation and Allergy-Drug Targets, 4: 281-286, 2005.

Gabay C. Interleukin-6 and chronic inflammation. Arthritis Research \& Therapy, 8: S3, 2006.

Gomez PF, Pillinger MH, Attur M, Marjanovic N, Dave M, Park J, Binagham CO 3rd, Al-Mussawir H, Abramson SB. Resolution of inflammation: prostaglandin E2 dissociates nuclear trafficking of individual NF-kappa B subunits (p65, p50) in stimulated rheumatoid synovial fibroblasts. Journal of Immunology, 175: 6924-6930, 2005.

Harris SG, Padilla J, Koumas L, Ray D, Phipps RP. Prostaglandins as modulators of immunity. Trends in Immunology, 23: 144-150, 2002.

Hirohashi N, Morrison DC. Low-dose lipopolysaccharide (LPS) pretreatment of mouse macrophages modulates LPSdependent interleukin-6 production in vitro. Infection and Immunity, 64: 1011-1015, 1996.

Hong $\mathrm{CH}$, Hur SK, Oh OJ, Kim SS, Nam KA, Lee SK. Evaluation of natural products on inhibition of inducible cyclooxygenase (COX-2) and nitric oxide synthase (iNOS) in cultured mouse macrophage cells. Journal of Ethnopharmacology, 83: 153-159, 2002.

Horwood NJ, Page TH, McDaid JP, Palmer CD, Campbell J, Mahon T, Brennan FM, Webster D, Foxwell BM. Bruton's tyrosine kinase is required for TLR2 and TLR4induced TNF, but not IL-6, production. The Journal of Immunology, 176: 3635-3641, 2006.

Hwang GS, Kim JY, Chang TS, Jeon SD, So DS, Moon CK. Effects of brazilin on the phospholipase A2 activity and changes of intracellular free calcium concentration in rat platelets. Archives of Pharmacal Research, 21: 774$778,1998$.

Hwang HS, Shim JH. Brazilin and Caesalpinia sappan L. extract protect epidermal keratinocytes from oxidative stress by inducing the expression of GPX7. Chinese Journal of Natural Medicines, 16: 203-209, 2018.

Im DY. Volatile compounds analysis of the extract from dried bark of Prunus sargentii and physiological activity of the 
main compound, benzaldehyde. Asian Journal of Beauty and Cosmetology, 12: 155-162, 2014.

Jeong KS, Park JH. A cytotaxonomic study of Galium (Rubiaceae) in Korea. Korean Journal of Plant Taxonomy, 39: 42-47, 2009.

Jones DL, Rando TA. Emerging models and paradigms for stem cell ageing. Nature Cell Biology, 13: 506-512, 2011.

Kim J, Lee CW, Kim EK, Lee SJ, Park NH, Kim HS, Kim HK, Char K, Jang YP, Kim JW. Inhibition effect of Gynura procumbens extract on UV-B-induced matrixmetalloproteinase expression in human dermal fibroblasts. Journal of Ethnopharmacology, 137: 427433, 2011.

Kim S, Kang BY, Cho SY, Sung DS, Chang HK, Yeom MH, Kim $D H$, Sim YC, Lee YS. Compound $K$ induces expression of hyaluronan synthase 2 gene in transformed human keratinocytes and increases hyaluronan in hairless mouse skin. Biochemical and Biophysical Research Communications, 316: 348-355, 2004.

Kirkwood TB. Understanding the odd science of aging. Cell, 120: 437-447, 2005.

Lawrence T, Willoughby DA, Gilroy DW. Anti-inflammatory lipid mediators and insights into the resolution of inflammation. Nature Reviews Immunology, 2: 787-795, 2002.

Lee HJ, Sim BY, Bak JW, Kim DH. Effect of Gami-sopungsan on inflammation and DNCB-induced dermatitis in NC/ Nga in mice. Korean Journal of Oriental Physiology \& Pathology, 28:146-153, 2014.

Lord PC, Wilmoth LM, Mizel SB, McCall CE. Expression of interleukin-1 alpha and beta genes by human blood polymorphonuclear leukocytes. The Journal of Clinical Investigation, 87: 1312-1321, 1991.

Moon CK, Park KS, Kim SG, Won HS, Chung JH. Brazilin protects cultured rat hepatocytes from $\mathrm{BrCCl}_{3}$-induced toxicity. Drug and Chemical Toxicology, 15: 81-91, 1992.

Namazi MR. Cetirizine and allopurinol as novel weapons against cellular autoimmune disorders. International Immunopharmacology, 4: 349-353, 2004.

Noman AS, Koide N, Hassan F, I-E-Khuda I, Dagvadorj,
Tumurkhuu G, Islam S, Naiki Y, Yoshida T, Yokochi T. Thalidomide inhibits lipopolysaccharide-induced tumor necrosis factor-alpha production via down-regulation of MyD88 expression. Innate Immunity, 15: 33-41, 2009.

Park JE, Cuong TD, Hung TM, Lee I, Na M, Kim JC, Ryoo S, Lee JH, Choi JS, Woo MH, Min BS. Alkaloids from Chelidonium majus and their inhibitory effects on LPSinduced NO production in RAW264.7 cells. Bioorganic \& Medicinal Chemistry Letters, 21: 6960-6963, 2011.

Puchtler H, Meloan SN, Waldrop FS. Application of current chemical concepts to metal-hematein and -brazilein stains. Histochemistry, 85: 353-364, 1986.

Roitt I, Brostoff J, Male D. Immunology sixth edition. Mosby, London, pp119-441, 2001.

Shon MS, Song JH, Kim JS, Jang HD, Kim GN. Anti-oxidant activity of oil extracted from Korean red ginseng and its moisturizing function. Asian Journal of Beauty and Cosmetology, 11: 489-494, 2013.

Talwar HS, Griffiths CE, Fisher GJ, Hamilton TA, Voorhees JJ. Reduced type I and type III procollagens in photodamaged adult human skin. The Journal of Investigative Dermatology, 105: 285-290, 1995.

Van Triel JJ, Arts JH, Muijser H, Kuper CF. Allergic inflammation in the upper respiratory tract of the rat upon repeated inhalation exposure to the contact allergen dinitrochlorobenzene (DNCB). Toxicology, 269: 73-80, 2010.

Xu X, Li H, Hou X, Li D, He S, Wan C, Yin P, Liu M, Liu F, $\mathrm{Xu} J$. Punicalagin induces Nrf2/HO-1 expression via upregulation of PI3K/AKT pathway and inhibits LPSinduced oxidative stress in RAW264.7 macrophages. Mediators Inflammation, 2015: 380218, 2015.

Yun KJ, Kim JY, Kim JB, Lee KW, Jeong SY, Park HJ, Jung HJ, Cho YW, Yun K, Lee KT. Inhibition of LPSinduced NO and PGE2 production by asiatic acid via NF-kB inactivation in RAW 264.7 macrophages: possible involvement of the IKK and MAPK pathways. International Immunopharmacology, 8: 431-441, 2008.

Zhang Y, Ramos BF, Jakschik BA. Neutrophil recruitment by tumor necrosis factor from mast cells in immune complex peritonitis. Science, 258: 1957-1959, 1992. 


\section{국문초록}

\section{브라질린의 RAW264.7 세포에서의 항염효과}

심중현

세명대학교 화장품·뷰티생명공학부, 충청북도 제천시, 한국

목적: 본 연구는 브라질린에 의한 RAW264.7 세포의 항염 효과를 확인하기 위하여 수행되었다. 방법: 브라질린이 RAW264.7세포 에 항염효과를 나타내는지 확인하기 위하여, $\mathrm{CCK}-8$ 실험법을 통한 세포생존률 측정, 실시간 유전자 중합효소 연쇄반응을 통한 싸 이토카인의 유전자 발현양상, 효소결합면역흡착검사법을 통한 $\mathrm{PGE}_{2}$ 와 산화질소의 생성 정도를 확인하였다. 결과: RAW264.7 세 포에 브라질린을 처리하여 세포독성을 확인한 결과, $1 \mu \mathrm{g} / \mathrm{mL}$ 이하의 농도로 처리시 독성을 나타내지 않음을 확인할 수 있었다. RAW264.7 세포는 LPS 자극에 의해 세포질 내 소과립이 증가되나 브라질린을 처리하면 대조군과 유사하게 세포질 내 소과립이 감 소하는 경향을 보였다. 본 연구를 통해 브라질린이 인터류킨 $1 \alpha$ (interleukin $1 \alpha, I L 1 \alpha$ ), 인터류킨 $1 \beta$ (interleukin $1 \beta, I L 1 \beta$ ), 인터류킨 6 (interleukin 6, $\amalg 6)$, tumor necrosis factor $\alpha(T N F \alpha)$ 유전자의 발현을 감소시킴을 확인할 수 있었다. 또한 산화질소의 생성을 감 소시키고 $\mathrm{PGE}_{2}$ 의 생성을 감소시킴을 통해 브라질린의 항염효과를 확인할 수 있었다. 결론: 본 연구를 통해 브라질린의 항염효과를 확인하였고, 브라질린이 항염 및 아토피를 타겟으로 하는 화장품 원료로서의 가능성을 제시하였다. 브라질린이 피부미용, 화장품, 건강식품 등의 산업 등에도 응용될 수 있을 것으로 여겨지며 그 가능을 확인하기 위해 브라질린이 염증세포에 미치는 기전연구가 필요할 것으로 보인다.

핵심어: 브라질린, 항염, 산화질소, $\mathrm{PGE}_{2}, \mathrm{TNF} \alpha$

이 논문은 2019학년도 세명대학교 교내학술연구비 지원에 의해 수행된 연구임.

\section{참고문헌}

백영미, 최정은, 이철우, 전영석, 한진택, 장성일, 유화승. 구판의 LPS로 유도된 염증 반응 억제 효과. 동의생리병리학회 지, 26: 26-34, 2012.

손명수, 송지혜, 김종식, 장해동, 김교남. 홍삼에서 추출한 오일의 항산화 및 보습활성. 아시안뷰티화장품학술지, 11 : 489-494, 2013.

이해진, 심부용, 박지원, 김동희. 加味消風散이 염증 및 아토피피부염 동물병태에 미치는 영향. 동의생리병리학회지, 28 : 146-153, 2014.

임도연. 화피의 휘발성 향기성분 조성과 주요성분인 Benzaldehyde의 생리 활성. 아시안뷰티화장품학술지, $12: 155-162$, 2014

정금선, 박재홍. 한국산 갈퀴덩굴속(Galium L.)의 세포분류학적 연구. 식물 분류학회지, 39: 42-47, 2009. 


\section{中文摘要}

\section{巴西木素 (Brazilin) 在RAW264.7细胞中的抗炎作用}

沁重鉉

世明大学化妆品 美容生命工学科，忠淸北道提川市，韩国

目的：探索巴西木素在RAW264.7细胞中的抗炎作用。方法：为了确定巴西木素对RAW264.7细胞的抗炎作 用, 测量了细胞生存能力, 细胞因子基因表达和前列腺素 $\mathrm{E}_{2}$ (prostaglandin $\mathrm{E}_{2}, \mathrm{PGE}_{2}$ ) 和一氧化氮 (nitric oxide, NO）的产生。结果：在这项研究中，阐明了巴西木素对白细胞介素 $1 \alpha （ i n t e r l e u k i n ~ 1 \alpha, I L 1 \alpha$ ），白细 胞介素 $1 \beta$ （interleukin $1 \beta, I L 1 \beta$ ），白细胞介素6（interleukin 6, IL6）和肿瘤坏死因子 $\alpha$ （tumor necrosis factor $\alpha, T N F \alpha$ ) mRNA表达和PGE 2 以及NO产生的抗炎作用。实时逆转录聚合酶链反应（real-time reverse transcription polymerase chain reaction, real-time RT-PCR) 显示, brazilin可增加ILIa、ILI 、IL6、

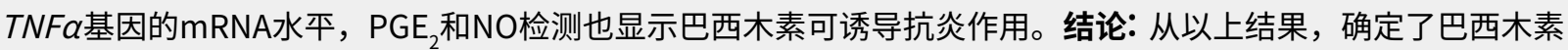
的抗炎作用, 该结果表明巴西木素可以成为抗炎和特应性皮炎的有效化妆品成分。基于这一结果, 将来进一步 研究巴西木素的机制，不仅要开发化妆品，还要开发药品或保健食品。

关键词: 巴西木素, 抗炎, 一氧化氮, PGE 2 , TNFa 
